EDUKACJA MIĘDZYKULTUROWA

2018, nr 1 (8)

ISSN 2299-4106

DOI: $10.15804 / \mathrm{em} .2018 .01 .07$

TOMASZ KaSPRZAK

\title{
Rodzina a edukacja wietnamskich uczniów w Republice Czeskiej - kontekst społeczny, kulturowy oraz prawny
}

Edukacja prowadzi do dorostości: prowadzi do wolności i odpowiedzialności, orientacji $w$ bogactwie różnych możliwości,

poglądów na świat.

Zdeněk Kratochvíl

Streszczenie: Od połowy lat 90. XX wieku w Republice Czeskiej coraz częściej podejmowana jest kwestia edukacji międzykulturowej. Głównym celem niniejszego opracowania jest charakterystyka ról rodzicielskich wietnamskich rodziców. W pracy przyjrzano się różnymi rodzajami postaw i wpływów rodziców na edukację dzieci. W artykule przedstawiono strategie edukacyjne podejmowane przez rodziców wietnamskich dzieci. Jednocześnie praca ujawnia znaczenie edukacji dla rodzin imigrantów. Z punktu widzenia wietnamskich rodziców najistotniejsze jest zapewnienie dzieciom pełnej integracji ze społeczeństwem czeskim.

Słowa klucze: Republika Czeska, mniejszość wietnamska, edukacja międzykulturowa, role rodzicielskie

\section{Wprowadzenie}

Dzieci imigrantów są tematem obecnych debat nad zjawiskiem migracji. Przedstawiane są bardzo często jako grupa „wciśnięta między dwie kultury” lub jako „pośrednicy”. Na podstawie danych Czeskiego Urzędu Statystycznego około 60.000 tys. obywateli Wietnamu mieszka w Republice Czeskiej i jest trzecią co do wielkości grupą imigrantów - po obywatelach Ukrainy i Słowacji. W przeciwieństwie do innych obcokrajowców, Wietnamczycy nie zamieszkują „centrum” kraju. Społeczność wietnamska rozmieszczona jest przede wszystkim w obszarze przygranicznym - w kraju morawsko-śląskim, karlowarskim, południowomorawskim, pilzneńskim. Cechą charakterystyczną Wietnamczyków mieszkających w Czechach jest progresywna struktura 
demograficzna, co oznacza, że największy odsetek osób: jest aktywnych zawodowo -22.620 tys. (93\%), ma stałe zamieszkanie (63\%) oraz jest w wieku 0-14 lat (21\%) (Pechová, 2007, s. 15). Co więcej, w porównaniu z innymi grupami imigranckimi, utrwalony jest wizerunek wietnamskiego „drugiego pokolenia”, który osiągnął sukces edukacyjny. Wietnamczycy „drugiej generacji” bardzo dobrze posługują się językiem czeskim, są zintegrowani ze społeczeństwem czeskim (Souralová, 2014).

Celem niniejszego opracowania było poznanie genezy i organizacji systemu edukacji wobec dzieci cudzoziemców w Republice Czeskiej. W szczególności uchwycenie wielopłaszczyznowej edukacji mniejszości wietnamskiej w Republice Czeskiej. Chodziło o dokonanie przeglądu działań, koncepcji, dominujących tendencji mentalnych w nastawieniach do Wietnamczyków. Potrzebne i pożyteczne było ukazanie kontekstu edukacji międzykulturowej w Republice Czeskiej, a także ukazanie ról rodzicielskich w edukacji wietnamskich uczniów. Dodatkowym celem było przedstawienie historii migracji Wietnamczyków - najpierw do Czechosłowacji, a później do Czech. Wybór Republiki Czeskiej jako państwa, w którym przeanalizowano edukację wietnamskich uczniów, wynikał z dwóch podstawowych powodów: (1) dużego doświadczenia w sferze zorganizowanego i instytucjonalnego kształcenia cudzoziemców, (2) okres po drugiej wojnie światowej w sposób szczególny łączył Czechosłowacką Republikę Socjalistyczną i Demokratyczną Republikę Wietnamu, przede wszystkim przez przyjęte umowy o wzajemnej pomocy. Pod koniec lat 40. ubiegłego wieku przybyła pierwsza grupa wietnamskich studentów. Punktem wyjścia do napisania tekstu była analiza czeskiej literatury przedmiotu (Broučka 2002, 2003; Kocourka 2006; Martínková 2004, 2007).

W ostatnich latach w Republice Czeskiej przeprowadzono szereg badań mających na celu określenie przebiegu edukacji młodych Wietnamczyków. Prowadzili je nie tylko socjolodzy, ale również pedagodzy i psychologowie. W jednych z ostatnich badań nad kontekstem społeczno-kulturowym edukacji młodych Wietnamczyków (por. Souralova 2014), wprowadzono koncepcję ról rodzicielskich. W dalszej części artykułu zostaną przedstawione główne założenia.

\section{Historia migracji Wietnamczyków do Czechosłowacji i Republiki Czeskiej}

Stwierdzić można, że migracje towarzyszyły nierozłącznie całym dotychczasowym dziejom ludzkości. W okresie międzywojennym terytorium dzisiej- 
szej Republiki Czeskiej należało do najbardziej zróżnicowanych etnicznie i narodowo regionów - ponad jedna trzecia ludności nie posiadała narodowości czeskiej. W czasach tzw. „socjalizmu państwowego” (1948-1989) migracja ludności była pod ścisłym nadzorem państwa czechosłowackiego. Pierwszą grupę wietnamskich migrantów stanowili studenci, którzy przybyli do Czechosłowacji na początku lat 40. ubiegłego wieku. Jednakże, najliczniejsza grupa wietnamskich migrantów przybyła pod koniec lat 50. i składała się głównie z sierot wojennych i dzieci żołnierzy wietnamskich.

Stosunki czesko-wietnamskie rozpoczęły się na początku lat 50 . ubiegłego wieku. W latach 60. na podstawie porozumienia o współpracy kulturalnej oraz umowy o współpracy naukowej i technologicznej do Czechosłowacji przybywali wietnamscy stażyści, praktykanci oraz pracownicy fizyczni, którzy zostali kształceni w przemyśle maszynowym, włókienniczym, spożywczym oraz obuwniczym. Po zakończeniu konfliktu amerykańsko-wietnamskiego migracja Wietnamczyków do Czechosłowacji wzrosła. W latach 1974-1977 przybyło ponad 5.000 tys. Wietnamczyków, głównie na podstawie nowo podpisanej umowy o szkoleniu obywateli Demokratycznej Republiki Wietnamu. Byli to głównie młodzi ludzie w wieku 17-25 lat, którzy kształcili się głównie w zawodach inżynieryjnych, w energetyce i budownictwie. Ich pobyt trwał 6 lat i składał się z sześciomiesięcznego kursu języka czeskiego, kształcenia zawodowego (od 2 do 3 lat) oraz zajęć praktycznych (od 2 do 3 lat). (Kocourek, 2006, s. 95-96).

Rząd Wietnamu zdobyte wykształcenie swoich obywateli w Czechosłowacji uznał za jedną z kluczowych kwestii odbudowy i rozwoju kraju. Wietnamczycy stanowili tanią siłę roboczą, zatrudniając się w zawodach, w których Czesi i Słowacy nie chcieli pracować. Liczba Wietnamczyków gwałtowanie wzrosła w latach 1979-1985. W 1981 roku w Czechosłowacji przebywało od 30.000 do 35.000 tys. obywateli Wietnamu (Kocourek, 2006, s. 96). Największa liczba pracowników wietnamskich została zarejestrowana w 1983 roku - wyniosła dokładnie 27.100 tys.

W połowie lat 80. nastąpił spadek liczby wietnamskich migrantów. Wynikało to przede wszystkim z końcem ważności umów między Wietnamem a Czechosłowacją (Brouček, 2002, s. 11). Jak podkreśla Stanislav Brouček badacz migracji wietnamskiej, w pierwszej połowie lat 80. migracja z Wietnamu do Czechosłowacji była najlepiej zorganizowana. Wietnamczycy przybyli do Czechosłowacji z bardzo dobrym przygotowaniem językowym. Najistotniejsze zmiany we współpracy obu państw nastąpiły po tzw. „aksamitnej rewolucji”. Wówczas większość umów politycznych i gospodarczych zosta- 
ło rozwiązanych (Martinková, 2003, s. 90). Transformacja ustrojowa oraz rozpad Czechosłowacji w 1993 roku zmusiły Wietnamczyków do powrotu do domu. Po 1994 roku część umów zostało odnowionych. Do Republiki Czeskiej przybywali Wietnamczycy za pomocą pośredników lub agencji rekrutacyjnych. Od 2006 roku znacznie wzrosła liczba Wietnamskich migrantów pracujących na podstawie umów o pracę. Głównym tego powodem było wprowadzenie regulacji prawnych w 2004 roku, które pozwoliły agencjom pośredniczącym na zatrudnienie zagranicznych pracowników (Janská, 2006). Wietnamczycy, którzy osiedlili się w Czechach po 1989 roku, bardzo często korzystali z sieci społecznościowych, aby rozpocząć pracę - głównie w handlu detalicznym. Początkowo wietnamscy imigranci skupiali się w regionach przygranicznych kraju, zajmowali się głównie sprzedażą tekstylii, elektroniki i artykułów spożywczych (Martínková, 2008).

Aktualnie społeczność wietnamska podzielona jest na kilka grup, opartych na okresie przybycia do Republiki Czeskiej. Pierwsza grupa, tzw. „staroświecka społeczność", przybyła do Czechosłowacji w latach 80. ubiegłego wieku. Ich przyjazd uzależniony był od międzynarodowych umów. Druga grupa, określana jako „postrewolucyjna”, przybyła do Republiki Czeskiej na początku lat 90. Trzecia grupa, tzw. „świeża fala” przybyła po 2000 roku (Pechová, 2007, s. 16-17).

\section{Kontekst edukacji międzykulturowej w Republice Czeskiej}

Czeski słownik pedagogiczny definiuje edukację międzykulturową jako „wysiłki, aby wychowywać i szanować kultury inne niż własna, przede wszystkim poprzez programy edukacyjne" (Pedagogický slovník). Edukacja międzykulturowa opiera się na równym dostępie grupy mniejszościowej do społeczeństwa większościowego. Jan Průcha (2000) uważa edukację międzykulturową za odpowiedź na wielokulturowe społeczeństwo. Autor określa edukację międzykulturową jako przygotowanie do realiów społecznych, politycznych i ekonomicznych, których uczniowie doświadczają w odmiennych kulturowo relacjach międzyludzkich. Jej tematyka obejmuje: pochodzenie etniczne, świadomość etniczną, mniejszość narodową, asymilację, rasizm, uprzedzenia i stereotypy. Edukacja międzykulturowa wyraża wysiłki, aby wychowywać i szanować inne kultury, poprzez programy edukacyjne (Průcha i Walterowá, 2003). W szczególności chodzi o wzbogacanie uczniów informacjami o ich własnej i innych kulturach, przyczyniając się do tolerancji i zapobieganiu rozwojowi rasizmu. 
W Republice Czeskiej edukacja międzykulturowa jest aktualnie pojmowana $\mathrm{z}$ różnych perspektyw:

1. perspektywa socjologiczna: mówi o zjawiskach społecznych, w których łączą się grupy społeczno-kulturowe z określonymi systemami wartości i postaw. Socjologia podejmuje problematykę stereotypów społecznych, tożsamości społecznej, tożsamości grupowej. Podstawowym zadaniem jest badanie, opis i wyjaśnienie zachowań grupowych - dużych i małych grup społecznych. Wśród czeskich socjologów bliskich edukacji międzykulturowej i działającej na jej rzecz jest m.in. Jiri Kocourek (por. m.in.: Kocourek, Řínová i Šimeček, 2014; Kocourek i Pechová, 2006). W tej perspektywie dominuje zainteresowanie grupami, społecznościami, zjawiskami ponadjednostkowymi;

2. perspektywa psychologiczna: w czeskim środowisku naukowym psychologia międzykulturowa jest bardzo mało znana, a jej nazwa terminologiczna nie została jeszcze ustalona. Możemy przez to wyróżnić trzy rozwiązania terminologiczne (za: Průcha, 2010, s. 15-16): (1) psychologia międzykulturowa wyrażania jest poprzez różnice międzykulturowe w edukacji (por. m.in.: Kolman, 2001; Průcha 2001, 2003), (2) psychologia międzykulturowa określana jest jako pewna forma ekspresji, (3) psychologia międzykulturowa określana jest mianem „psychologii transkulturowej";

3. perspektywa pedagogiczna: wyraźnie podkreśla zależność między kulturą, sytuacją społeczną i miejscem rodzin w środowisku a powodzeniem szkolnym uczniów - głównie pochodzących z mniejszości narodowych i etnicznych. W czeskiej pedagogice międzykulturowej najczęściej zgłębiane obszary problemowe to: sytuacja imigrantów, ich dzieci oraz społeczeństw (por. m.in.: Šišková, 1998, 2001) oraz pogranicze kulturowe w kontekście wielokulturowości.

W ciągu ostatnich kilku dziesięcioleci zainteresowanie edukacją międzykulturową znacząco wzrosło. W Republice Czeskiej wciąż nadal jest wiele osób, które nie posiadają żadnego doświadczenia z członkami innymi kultur, posiadając przy tym zniekształcony ich obraz. Z drugiej strony, czeska szkoła integruje dzieci cudzoziemców poprzez nauczanie języka czeskiego, jednak zaniedbuje kształcenie i wspieranie rozwoju społecznej i kulturowego (Šišková, 2008, s. 35).

Edukacja międzykulturowa w Republice Czeskiej rozumiana jest na dwóch poziomach (za: Průcha, 1991):

- jako proces polegający na tworzeniu sposobów pozytywnej oceny od- 
miennych systemów kulturowych i na tej podstawie regulowanie własnych zachowań wobec członków innych kultur;

- jako program edukacyjny, który zapewnia uczniom z mniejszości narodowych, etnicznych i religijnych dostęp do treści edukacyjnych dostosowanych do specyficznych potrzeb językowych, psychologicznych i kulturowych tych uczniów.

\section{Uwarunkowania społeczno-kulturowe edukacji wietnam- skich uczniów}

Szacunek dla edukacji jest ważną cechą wietnamskiej kultury. Ta cecha jest widoczna także dzisiaj w środowisku wietnamskich rodzin na ziemiach czeskich. Wietnamscy uczniowie w opinii nauczycieli są bardzo sumienni. Czeska edukacja znacząco różni się wietnamskiej. Główne różnice dotyczą z jednej strony, rozwoju krytycznego myślenia społeczeństwa postmodernistycznego. $\mathrm{Z}$ drugiej strony, wietnamskie szkoły kładą nacisk na rozwój myślenia matematycznego, a nauki społeczne nie są cenione w społeczeństwie pragmatycznym. Dla młodych Wietnamczyków nadrzędnym celem w życiu jest edukacja, gdyż wykształcenie w społeczności wietnamskiej jest bardzo ważne.

Rodzina w wietnamskim społeczeństwie posiada bardzo silną pozycję. Wychowanie w wietnamskiej rodzinie oparte jest na zasadach konfucjanizmu. Dzieci powinny pokazać bezwzględne posłuszeństwo wobec rodziców - zwłaszcza ojca. Do podstawowych cech tradycji wietnamskiej rodziny możemy zaliczyć: posłuszeństwo, solidarność z bliskimi i dalekimi krewnymi, wzajemna pomoc rodzinna. Tradycje te są mniej lub bardziej szanowane wśród młodego pokolenia, które urodziło się w Czechach lub dorastało w tym kraju od najmłodszych lat. Nie posiadają związku kulturowego z Wietnamem

Badania nad relacjami rodzic-dziecko i rolą edukacji w wietnamskiej rodzinie prowadziła Adelá Souralová (2014, s. 323-327). Autorka wymienia pięć ról rodzicielskich, w odniesieniu do edukacji ich dzieci. Wszystkie te role są nierozerwalnie związane z doświadczeniami migracyjnymi rodziców i kontekstem ich sytuacji po migracji:

- rodzice jako twórcy możliwości: rodzice podkreślają, że przyjechali do Republiki Czeskiej, aby żyć lepiej. Przyjazd oznaczał lepsze warunki pracy, lepiej płatną pracę, a także zapewnienie dzieciom lepszego systemu edukacyjnego. Rodzice odgrywają rolę twórców szans, ponieważ ich imigracja była całkowicie ukierunkowana na dzieci. Przybyli do 
Czech tylko dla swoich dzieci, intensywnie pracując nad zapewnieniem im kapitału społecznego. Pragną powrócić do Wietnamu, gdy ich dzieci staną się dorosłe i niezależne;

- rodzice jako sponsorzy sukcesu: możliwości wynikające z migracji rodziców mogą być w pełni wykorzystane tylko wtedy, gdy dzieci są wyposażone w wystarczający kapitał społeczny. Włączenie się do grupy gospodarczych imigrantów pociąga za sobą dwie zasadnicze zmiany w biografiach wietnamskich rodziców. Pierwsza zmiana ma charakter jakościowy i powoduje zmianę ich dotychczasowego życia zawodowego. Niezależnie od ich zawodu i wykształcenia, przed przybyciem do Republiki Czeskiej w większości pracują jako przedsiębiorcy czy sklepikarze. Druga zmiana ma charakter ilościowy i przekierowuje ich dotychczasowe plany finansowe. Rodzicom trudno jest utrzymać równowagę między pracą a życiem rodzinnym - „robiąc wszystko dla dzieci, nie pozostając z nimi";

- rodzice jako źródło aspiracji: aspiracje edukacyjne dzieci opierają się na świadomości, że ich rodzice nie posiadali takich samych szans i możliwości. Niewykorzystane szanse edukacyjne rodziców są postrzegane jako podstawowy krok w kierunku edukacji dzieci. Dlatego uczą się nie tylko dla samych siebie, ale także dla swoich rodziców, co może ich stawiać w sytuacjach nacechowanych znaczną presją i oczekiwaniami;

- rodzice jako opiekunowie edukacji: rodzice motywują pozytywnie swoje dzieci - dobre oceny nagradzają upominkami. Moment krytyczny następuje, gdy dziecko zaczyna otrzymywać złe oceny;

- rodzice jako „dostawcy” lepszej przyszłości: rodzice pragną zapewnić swoim dzieciom lepszą przyszłość od własnej. Pranee Liamputtong (2006) w swoich badaniach wykazała, że kobiety definiują sukces swojego macierzyństwa w odniesieniu do osiągnięć ich dzieci w edukacji i na rynku pracy. Nacisk na edukację jest istotną częścią definicji dobrego rodzicielstwa w opinii Wietnamczyków, a ona sama postrzegana jest jako sposób na wspinanie się po drabinie społecznej. Ważne jest nie tylko to, aby dziecko było kształcone, ale żeby posiadało najlepsze wykształcenie, a ich oceny powinny być lepsze niż czeskich rówieśników. Tylko wtedy mogą przezwyciężyć piętno bycia obcokrajowcem i być pozytywnie postrzeganym przez czeskie społeczeństwo.

Analizując rolę edukacji w relacjach rodzic-dziecko, oczywistym wydaje się, że edukacja jest kwestią rodziny w co najmniej dwóch aspektach. Po pierwsze, edukacja dziecka powinna zapewnić ciągłość życia w Republice 
Czeskiej. Po drugie, osiągnięcia edukacyjne dzieci przynoszą prestiż całej rodzinie, a przede wszystkim tym rodzicom, którzy podążają za argumentem, że wykształcone dziecko jest zintegrowane z czeskim społeczeństwem. Zapewnienie dostępu do edukacji wydaje się być głównym celem migracji wietnamskich rodziców. Sukces edukacyjny prowadzący do pomyślnej integracji na rynku pracy jest oznaką „dobrego” rodzicielstwa. (Souralová, 2014, s. 328).

Wiele wietnamskich dzieci wychowywanych jest przez czeskie nianie. Rodzice zatrudniają nianie, aby opiekowały się dziećmi podczas ich pracy oraz wyposażyły dzieci w wiedzę, której sami nie mogą zapewnić (m.in. kompetencje językowe, przekazywanie pamięci kulturowej). Istnieje kilka powodów, dla których wietnamscy rodzice zatrudniają nianie. Wspomnieć należy przede wszystkim o długich godzinach pracy, braku wsparcia ze strony dalszej rodziny czy niewystarczającej pomocy ze strony państwa (trudny dostęp do publicznych przedszkoli). Trzeba podkreślić, że niania zatrudniana nie jest po to, aby edukować dziecko i pomagać mu w integracji z czeskim społeczeństwem, ale ma służyć jako substytut pracującej matki. Nianie odgrywają trzy podstawowe role (za: Souralová 2014, s. 330):

- są nieuchronnie przedstawiane jako pierwsi opiekunowie o kluczowym znaczeniu dla dzieci. Niania odpowiedzialna jest za rozwój intelektualny dziecka. Ta kwestia wydaje się szczególnie ważna w odniesieniu do socjalizacji językowej;

- podczas codzienne opieki przekazują nieformalny (ukryty) program nauczania dzieciom. Przekazywany jest nie tylko język, ale co ważniejsze - idee, wartości, oraz tradycje;

- odgrywają istotną rolę w kształceniu dzieci, pomagając im w pracach domowych oraz komunikowaniu się z instytucjami szkolnymi.

Nianie w wielu przypadkach stały się nie tylko pośrednikami między szkołą a rodzicami, ale w rzeczywistości odpowiedzialnymi za realizację planu edukacyjnego rodziców wobec dziecka.

\section{Prawne aspekty edukacji wietnamskich uczniów w Repu- blice Czeskiej}

W Republice Czeskiej kształci się około 2\% uczniów, dla których język czeski jest językiem obcym ${ }^{1}$. Edukacja uczniów-cudzoziemców jest jednym z istot-

1 Na podstawie: Český statistický úřad - Národnostní struktura obyvatel. https:// www.czso.cz/documents/10180/20551765/170223-14.pdf (dostęp: 10.09.2017). 
nych obszarów kompetencji Ministerstwa Edukacji, Młodzieży i Sportu (cz. Ministerstvo školství, mládeže a tělovýchovy České republiky). Prawo do nauki jest jednym z fundamentalnych praw człowieka. Przyjęte w Republice Czeskiej rozwiązania przyznają wszystkim dzieciom przebywającym na terenie państwa czeskiego prawo do nauki. Ustawa nr 273/2001 o prawach mniejszości narodowych (zákon 273/2001 Sb. právech př́slušníkủ národnostnich menšin) jako pierwsza gwarantowała prawo do nauki dzieciom cudzoziemców. Powstanie ustawy wynikało przede wszystkim z traktatów międzynarodowych, przede wszystkim: Konwencji o prawach dziecka (art. 28), Powszechnej Deklaracji Praw Człowieka (art. 26) oraz Karty Podstawowych Praw i Wolności (art. 33). Przepisy chronią cudzoziemców przed dyskryminacją i tym samym gwarantują prawo do nauki.

Wietnamczycy mieszkający w Republice Czeskiej prawo do nauki mają określone w ustawie o szkolnictwie nr 531/2004 stanowiącej, iż „osoby, które nie są obywatelami Republiki Czeskiej i legalnie w niej zamieszkują, posiadają dostęp do podstawowego kształcenia na tych samych warunkach co obywatele Republiki Czeskiej”. Na tej podstawie, władze lokalne i dyrekcja szkoły są zobowiązane zapewnić:

- bezpłatne przygotowanie do podjęcia nauki, w tym przede wszystkim naukę języka czeskiego dostosowanego do potrzeb ucznia;

- wsparcie w nauczaniu języka ojczystego ucznia, we współpracy z krajem pochodzenia ucznia.

Na podstawie wyników badań przeprowadzonych przez Yvonę Kostelecką i Antonína Jančaříka (2014), można stwierdzić, że jednym z najważniejszych czynników warunkujących pomyślną integrację dzieci migrantów, jest umiejętność porozumiewania się w języku czeskim. W 2012 roku zmieniono ustawodawstwo czeskie w celu zapewnienia bezpłatnego przygotowania do podjęcia nauki szkolnej, w tym zajęć z języka czeskiego (Kostelecká i Jančařík, 2014, s. 10). Przygotowanie językowe odbywa się dla maksymalnie 10 uczniów. Najniższa liczba uczniów nie jest określona, dlatego nawet dla jednego ucznia tego typu zajęcia odbywają się. Całkowita długość przygotowania językowego ustalona jest na conajmniej 70 godzin lekcyjnych i może trwać maksymalnie sześć miesięcy. Treść nauczania języka czeskiego zdeterminowana jest przez oczekiwane wyniki, określone przez Ramowy Program Edukacyjny. Podkreśla się, że określony metody i treści nauczania, muszą uwzględniać potrzeby poszczególnych uczniów. Po ukończeniu przygotowania językowego uczeń otrzymuje certyfikat. Głównym zadaniem programu jest przede wszystkim nauczenie języka czeskiego, usunięcie barier komu- 
nikacyjnych oraz integracje uczniów różnych narodowości z rówieśnikami i resztą społeczeństwa.

Szkoły mogą także wykorzystać ustawę nr 147/2011 o kształceniu uczniów ze specjalnymi potrzebami edukacyjnymi (zákon 147/2011 Sb. o vzdělávání dětí, žákư a studentů se speciálními vzdělávacími potřebami), dzięki której nauczyciel może zintensyfikować proces nauczania ucznia z niedostateczną znajomością języka czeskiego.

W grudniu 2000 roku rząd Republiki Czeskiej przyjął koncepcję integracji imigrantów. Koncepcja określa działania wspierające integrację, grupy docelowe (na których koncentrują się działania) oraz role poszczególnych ministerstw. Formułuje poszczególne warunki integracji, które są niezbędne do skutecznego zaangażowania w obszary życia społecznego. Możemy do nich zaliczyć: (1) znajomość języka czeskiego, (2) samodzielność ekonomiczna imigrantów, (3) relacje imigrantów z członkami społeczeństwa czeskiego. Wspomniane regulacje prawne oraz zalecenia tworzą stosunkowo jednolite zasady traktowania mniejszości narodowych i etnicznych, a także stanowią asumpt do nowych podejść.

\section{Podsumowanie}

Rozważania o edukacji międzykulturowej są bardzo różnie przyjmowane, m.in. w zależności od doświadczeń społeczeństw, a także poszczególnych ludzi oraz swoistych odmian wielokulturowości (Lewowicki, 2015, s. 14). Analizując powyższe dane i wyniki badań, należy zauważyć, że rodziny wietnamskich imigrantów mieszkających w Republice Czeskiej, są patriarchalne, a ich edukacja ma charakter konfucjański. Pielęgnowanie tradycyjnych wartości, takich jak: szacunek dla starszych, posłuszeństwo, praca na rzecz rodziny, jest podstawą funkcjonowania społeczności wietnamskiej. Wynika to głównie z edukacji konfucjańskiej, a także fundamentalnej roli rodziny w przetrwaniu narodu wietnamskiego. Czeskie szkoły na przełomie XX i XXI wieku są świadkami dużego wzrostu liczby wietnamskich dzieci. Ich obecność może być postrzegana jako nowy etap koegzystencji czesko-wietnamskiej. Dzieci wietnamskie uczą się szybko i łatwo, a najbliższa rodzina zachęca je do osiągania jak najlepszych wyników. W kontaktach z czeskimi rówieśnikami są bezkonfliktowe, otwarte, łatwo nawiązują relacje społeczne. Jeżeli porównamy wietnamską młodzież i pokolenie ich rodziców możemy zauważyć różnice w stopniu integracji ze społeczeństwem czeskim. Starsze pokolenie żyje w zamkniętych społecznościach, ma trudności w porozumie- 
waniu się w języku czeskim. Młodzi natomiast, bardzo dobrze mówią po czesku, wybierają tradycje i wartości czeskiego społeczeństwa.

\section{Bibliografia}

Bartoňová, M. 2004. Strategie a přistupy k efektivnějšímu vzdělávání romského etnika v českém školství. W: Vítková, M. red. Integrativní školní (speciální) pedagogika. Základy, teorie, praxe. Brno: MSD (druhé vydání), ss. 204-218.

Brouček, S. 2002. Vietnamské etnikum v lokálním prostředí české majority. Praha: MZV, ss. 13-84.

Janská, E. 2006. Druhá generace cizinců v Praze: příklad dětí z mateřských školek a jejich rodičů. Geografie-Sborník České geografické společnosti, 2(111), ss. 198-214.

Kocourek, J. 2006. Vietnamci v současné ČR. W: Kocourek, J. i Pechová, E. red. S vietnamskými dètami na českých školách. Praha: $\mathrm{H}+\mathrm{H}$, ss. 102-118.

Kostelecká, Y. i Jančařík, A. 2014. The process of Czech language acquisition by foreign pupils at lower secondary school. ERIES Journal, 1(7), pp. 7-13. Lewowicki, T. 2015. Wielokulturowość i globalizacja a strategie edukacji międzykulturowej. Pogranicze. Studia Społeczne, XXV, ss. 13-24.

Liamputtong, P. 2006. Motherhood and „moral career”. Discusses of good motherhood among Southeast Asia immigrant women in Australia. Qualitative Sociology. 1 (29), pp. 25-53.

Martinková, Š. 2003. Vietnamská menšina v Praze. Praha: Diplomova práce. Katedra kulturologie FF UK, ss. 90-99.

Martínková, Š. 2008. Sociabilita vietnamského etnika v Praze. W: Uherek, Z., Korecká, Z. i Pojarová, T. red. Cizinecké komunity z antropologické perspektivy, vybrané př́pady významných imigračních skupin v České republice. Praha: Etnologický ústav AVČR, ss. 167-210.

Pechová, E. 2007. Migrace z Vietnamu do České republiky v kontextu problematiky obchodu s lidmi a vykořistování. Praha: La Strada České republiky, ss. $16-20$.

Průcha, J. 1991. Multikulturní výchová a vzdělávání. Pedagogika. 1, ss. 269$-276$.

Průcha, J. I Walterová, E. 2003. Pedagogický slovník. Praha.

Průcha, J. 2010. Interkulturní psychologia. Sociopsychologické zkoumání kultur, etnik, ras a národu (druhé, rozšírené vydání). Praha: Portál, ss. 15-16. 
Souralová, A. 2014. Vietnamese parents and Czech Nannies: Second-generation immigrant children and their educators. Journals of Education Culture and Society. 1, pp. 320-333.

Šišková, T. 2008. Výchova k toleranci a proti rasismu. Praha: Portál Freidingerová, T. 2014. Vietnamci v Česku a ve světě: migrační a adaptační tendence. Praha: Sociologické nakladatelství v koedici s Př́rodovědeckou fakultou Univerzity Karlovy.

Zákon 273/2001 Sb. právech příslušníků národnostních menšin.

Zákon 147/2011 Sb. o vzdělávání dětí, žáků a studentů se speciálními vzdělávacími potřebami.

\section{Family and education of Vietnamese learners in the Czech Republic - the social, cultural and legal context}

Abstract: Since the mid-1990s, the issue of intercultural education has been increasingly addressed in the Czech Republic. The main purpose of this study is to characterize the parental roles of Vietnamese parents. The work looked at different types of attitudes and influences of parents on the education of children. The article presents educational strategies undertaken by parents of Vietnamese children. At the same time, the work reveals the importance of education for immigrant families. From the point of view of Vietnamese parents, the most important is to provide children with full integration with the Czech society.

Keys words: Czech Republic, Vietnamese minority, intercultural education, parental roles 